\title{
Impact of Development Expenditure on Economic Development of Pakistan
}

\author{
Mohammad Salih Memon \\ Assistant Professor Department of Business Administration* \\ saleh.memon@salu.edu.pk \\ Mohammad Ali Pasha Panhwar \\ Lecturer, Department of Economics \\ University of Sindh, Jamshoro, Sindh, Pakistan \\ Dr. Chandan Lal Rohrra \\ Professor Department of Business Administration* \\ *Shah Abdul Latif University Khairpur, Sindh, Pakistan
}

\section{Abstract}

\begin{abstract}
This study was conducted in the light of fiscal plan of Pakistan and secondary data was used from State Bank of Pakistan and Ministry of Finance for year 2000-01 to 2009-10 and linear regression was applied for checking the above said impact, and concluded that the value of R-square which states that all six independent variables of economic development are rightly predicting the development expenditure while using general approach but when we used the stepwise regression method which clearly escaping or leaving three of them and only using remaining three variables namely Health \& Nutrition, Exports, and Imports are rightly predicting the development expenditure (Dependent Variable) and states that Health \& Nutrition Expenditure is negatively related with development expenditure which is purely policy matter, and Exports, Imports are positively related with development expenditure it is right in the case of exports only but needs serious attention by the policymakers in the case of Imports.
\end{abstract}

\section{Council for Innovative Research}

Peer Review Research Publishing System

\section{Journal: International Journal of Management \& Information Technology}

Vol. 10 No. 2

editorsijmit@gmail.com

www.ijmit.com/ois 


\section{Introduction}

Public expenditure is playing an important role in the formation of physical and human capital and proven to be the effective tool in enhancing the growth of economy. In the history of Pakistan public expenditure remained under pressure during last five years.

Table: Trends in Components of Expenditure (as \% of GDP)

\begin{tabular}{|c|c|c|c|c|c|c|c|c|c|}
\hline \multirow[t]{2}{*}{$\overline{\text { Year }}$} & \multirow[t]{2}{*}{$\begin{array}{c}\text { Total Exp. } \\
\text { (A) }\end{array}$} & \multirow[t]{2}{*}{$\begin{array}{l}\text { Current } \\
\text { Exp. (B) }\end{array}$} & \multirow[t]{2}{*}{$\begin{array}{c}\text { Interest } \\
\text { Payments (C) }\end{array}$} & \multirow[t]{2}{*}{$\begin{array}{c}\text { Defence } \\
\text { (D) }\end{array}$} & \multirow{2}{*}{$\begin{array}{l}\text { Develop- } \\
\text { ment Exp } \\
\text { (E) }\end{array}$} & \multirow{2}{*}{\begin{tabular}{|c|} 
Non Interest \\
Non- \\
DefenceExp \\
(A-C-D)
\end{tabular}} & \multirow[t]{2}{*}{$\begin{array}{l}\text { Fiscal } \\
\text { Deficit }\end{array}$} & \multirow{2}{*}{\begin{tabular}{|c|} 
Revenue \\
Defleit/Sur- \\
plus (TR-Total \\
CE)
\end{tabular}} & $\begin{array}{c}\text { Primary } \\
\text { deficit }\end{array}$ \\
\hline & & & & & & & & & $\begin{array}{c}\text { (TR-NI } \\
\text { Exp) }\end{array}$ \\
\hline $2006-07$ & 19.5 & 14.9 & 4.2 & 2.7 & 4.7 & 12.6 & 4.1 & -0.8 & -1.2 \\
\hline $2007-08$ & 21.4 & 17.4 & 4.8 & 2.6 & 4.2 & 14.0 & 7.3 & -3.3 & -2.5 \\
\hline $2008-09$ & 19.2 & 15.5 & 5.0 & 2.5 & 3.6 & 11.7 & 5.2 & -1.4 & -0.2 \\
\hline $2009-10$ & 20.2 & 16.7 & 4.4 & 2.5 & 3.5 & 13.3 & 6.2 & -2.7 & -1.8 \\
\hline $2010-11$ & 18.9 & 15.9 & 3.9 & 2.5 & 2.8 & 12.5 & 6.5 & -3.5 & -2.6 \\
\hline $2011-12$ & 19.8 & 15.5 & 4.5 & 2.5 & 3.6 & 12.6 & 6.8 & -2.8 & -2.3 \\
\hline $2012-13 \mathrm{~B}$ & 19.0 & 14.6 & 4.0 & 2.3 & 4.4 & 12.7 & 4.7 & -0.3 & -0.7 \\
\hline
\end{tabular}

Expenditure is qualified as the development expenditure when the beneficiary is the developing country and the same amount of expenditure is not available for developed countries, these amounts are without revenues resulting from the fees reductions accorded under the international registration system and for applicants from the developing countries.

There is no any single standard to compare the development of economies of various countries in the world. There are so many factors, such as; GNP growth, CPI, investments, trade, etc. when we are talking about economic development means the overall growth of different sectors of the economy.

It means development is a multidimensional process comprises of the reorganization of entire economic and social systems. Furthermore the improvements in total output, and income involves drastic changes in the structure of the institutions, society, and administration, also in population attitudes, custom, and beliefs(Micael \& Smith, 2006).

\section{Obstacles of Economic Development in Pakistan}

The obstacles which are affecting the economic development of the Pakistan are categorized in three heads:

A. Social and Cultural Obstacles: the socio-cultural behavior of the people also creates some times problem for the development of the country. In Pakistan we have more than 50 percent of population is uneducated. They are not of the opinion that development takes place in the country/city/village. Most of the people got conservative approach, and they are pride of their so called culture, lack of self-confidence. The occupational class, mostly from villages impedes the economic development; also the religious beliefs of the most of the population condemn the accumulation of wealth. Unnecessary expenditure on marriages, death, births, and class pride has drastically reduced domestic saving and badly affecting economic development. The basic needs of people became unsatisfied largely. We agree here about the socio-cultural behavior have drastically impeded the economic progress of the Pakistan. But we do not have to forget the adoption of socio-cultural behavior of western's brought down the quality of life as well.

B. Political and Administrative Obstacle: when we are talking about economic developmentmeans we are talking about stable political system in the country. If there are frequent changes in the governments, it will badly affecting the economic performance by changing/altering in the previous government plans.

The planning bodies and all others are known as administration and they must be loyal to their country, they must be competent, honest, and sympathetic in the performance of their duties.

In Pakistan since its inception many governments changed, and each one when coming in to power condemning the planning of last one and forming their own plans, strategies, concerned with the development of economy, but left the claim without achieving their predetermined objectives. Due to that political government, the administration of different departments/institutions is generally weak, less competent; their self-interests are dominating over the national interests, which is again a big barrier/obstacle towards the economic development of Pakistan.

\section{Literature Review}

There can be somehow doubts about nature of economy, and characteristics of its structure affect the capability to tax as well as its category that be able to be imposed.

Typical economic loom to taxation and expansion depends on top of how economic alteration affects the evaluation of tax structure. In this loom of alteration in tax, the tax structure reflects the structural changes. For example; on its last legs unofficial sector expends the levy net, the enlargement of big dense craft a vehicle for obedience, and enhancement of financial services motivates transparent accounting procedures which facilitates taxation. These types of structural approaches are depending in the influential commentaries of (Tanzi V. , 1987) and the assessment of the matter by 
(Burgees \& Stern, 1993). Significant offerings were center of attention on definite economic strait, includes (Gordon \& Li, 2009) focuses on the connection among taxation as well as recognized finance, with (Kleven, Kreiner, \& Saez, 2009) emphasized third revelry coverage with the help of companies.

Very definitely the typical economic loom studied the effects of tax structure lying on the overall economy; well organized tax system can reduce the competence of losses obligatory via taxes along with increase the development rate in endogenous escalation sculpt (Barrow, 1990). Tax structure in the developing country's context takes in to consideration the information regarding behavioral responses required by governments as in the literature review cited by (Newbery \& Stern, 1987), and (Gordon, Roger, 2010).

The standard economic vision encompass also by means of the matter of management plus obedience (Slemord \& Yitzhaki, 2002) for the overview:

Figure: Standard Approaches

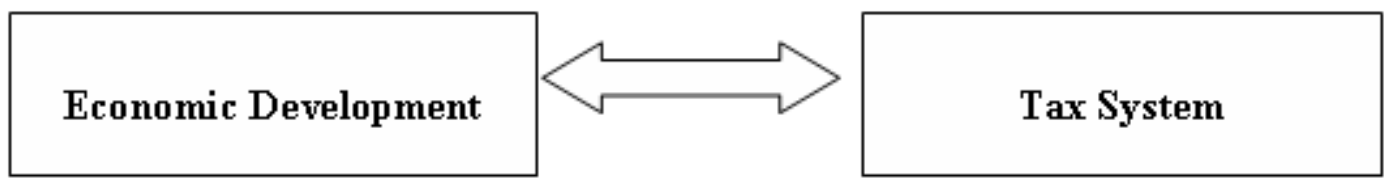

Those issues took center juncture in the prominent research of (Bird \& Oldman, 1980). Analyzing the current experience through lends of effective administration, (Bird R. , 2004) observed that most excellent tax plan into the world is importance modest if it cannot be put into practice successfully.

The greater dependence on taxes of trade than income taxes in the countries whose economy is poor, has been pointed out and discussed by many researchers like; (Hinrichs, 1996), (Tanzi, Vito, 1992), and (Burgees \& Stern, 1993) for so early contribution.

But economic development cannot mechanically be translated in to increasing tax, even in speedy mounting economies; such like India, plus China, verdict taken by the states are looked-for to earn a return in the form of huge tax split in gross domestic production.

(Piketty \& Qian, 2009) fall out about the increase in income tax exemption in India have idle at approximately $0.5 \%$ of gross domestic production since 1986.

Administrative and compliance was specified a innermost role, nearly all of the efforts in standard economic loom has got tiny space for endogenous administration behavior. By matching history of how levy system have develop, like (Brewer, 1989), \&(Dincecco, 2011) put a big deal of emphasizing on motive and behavior of government for increasing taxes (Brautigam, Fjeldstad, \& Moore, 2008).

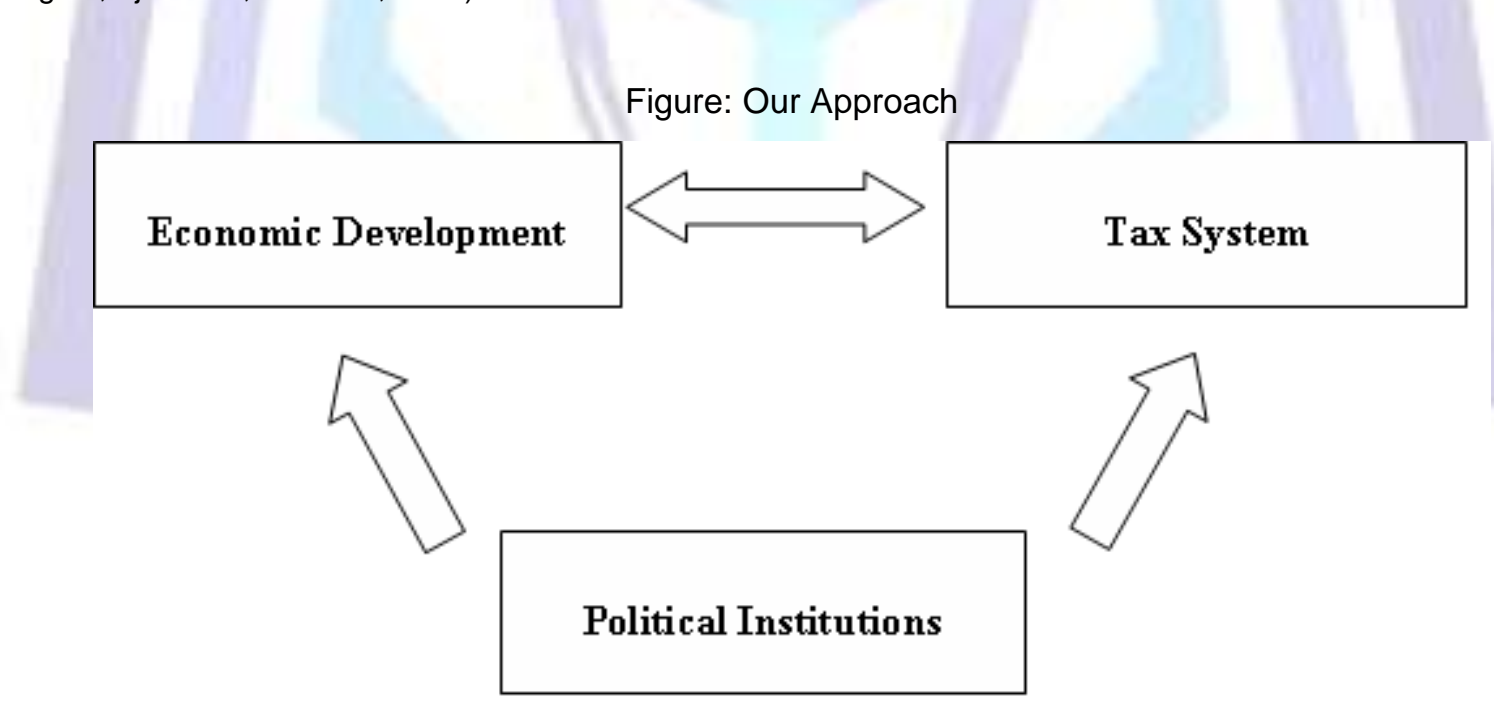

The first feature of the approach is in the direction of argue the standard approach through giving not merely economic aspect but also the political issue which perform key role in analysis of levy and expansion (Pearson \& Tabellini, 2003) which looked to political intention as an essential figure for sympathetic that how improvement proceeds plus to clarify why the countries decay and other grow.

This loom was analyzed and observed tax obedience as something additional as a technical concern, and pragmatic obedience also replicate the fundamental spur of policymakers for improvement of taxation structure plus to guarantee that levies are paid. In this sense this approach was related to the work of (Cukierman, Edward, \& Tabellini, 1992) that how use of seignior age depending on the competence of taxation structure, as well as how strategic option depends on polarization and political strength. 
An overview on the work of political economics by different economists on how any state's fiscal power evolves. Many researchers emphasize the role of government as a key role to form a fiscal capacity; especially the center of attention is welfare in stimulating demands for the capacity (fiscal). There are number of case studies for this research was used; (Brewer, 1989), (Bonney, 1999), \&(O'Brien, 2005). But some endeavor at wider general approach in the world by (Schumpeter, 1918), (Tilly, 1985), (Levi, 1988), \&(Hoffman \& Rosenthal, 1997).

While looking in to the fact many governments are unable to imposed broad-based taxes is often observed in the fragile states in deprived countries by improvement researcher, such as, (Migdal, 1988)

Political scientist and sociologist sometimes thrust the position of levy in development even more; by giving argument that levy can be mechanism for economic and political alteration. This can be analyzed from the figure: wherever political association represents to the expending tax sphere.

Figure: Extended Approaches

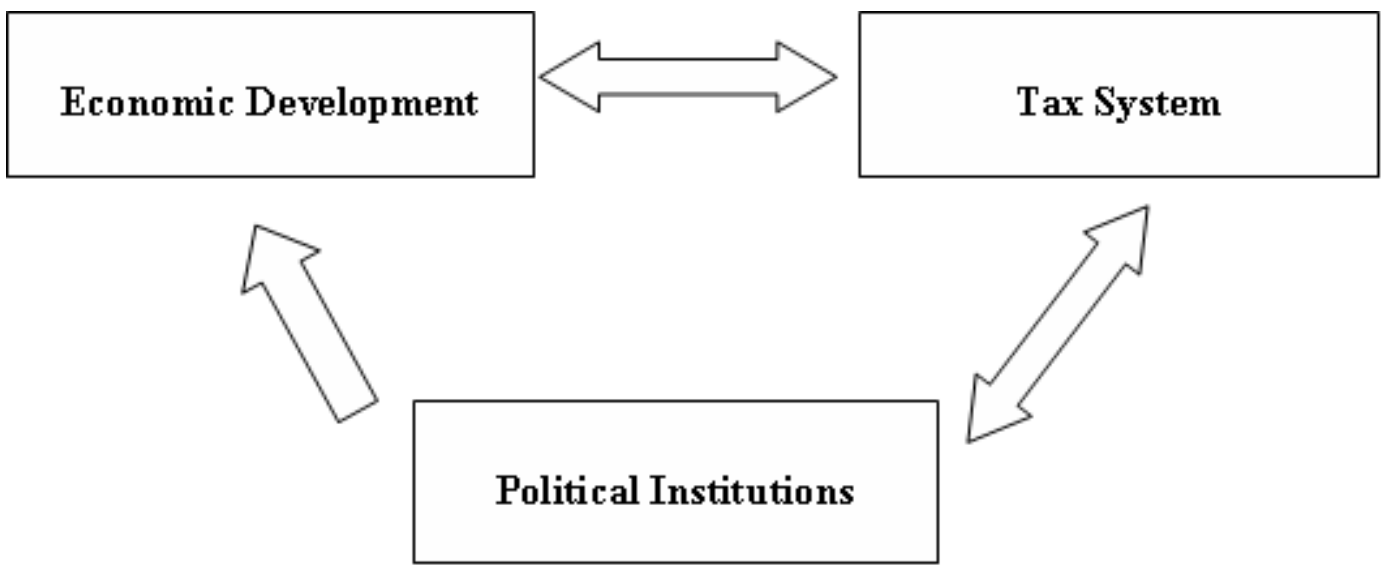

The study of (Hwanjoon, 2000) was to compare the income transfers and anti-poverty usefulness of taxes between western wellbeing states.

While looking at the expenditure side, there are several categories of expenditures, and policies regarding expenditures influencing on long-term growth. The efforts on endogenous growth theory suggested that: it is the fiscal plan which can endorse or impede economic growth from side to side its impacts on decisions concerned with the investment in physical as well as human capital (Barro, R J, 1991).

Increase in the expenditure on education, health, infrastructure, and research and development can enhance long-term growth (Barro, R J, 1990), and (Romer P. M., 1990). Higher growth will generate greater fiscal resources for financing the spending on human capital.

On the finance side extensive literature is available on the association among outside debt as well as economic activity, literature pointed out that overseas borrowing got optimistic impact on investment as well as growth up to a convinced level, otherwise its brunt is pessimistic.

(Burnside \& Dollar, 2000) Cleared that foreign aid increase the growth only in excellent plan setting. But current research concluded that these findings robust (Easterly W. , 2003). This issue has unspecified weight in the light of MDGS, since one of the objective is to raise flow of aids developing countries (Blejer \& Chu, 1989).

The experiential study, basically on manufacturing countries, has referred to comprehend the environment under which fiscal consolidation directed to increase output. (Giavazzi \& Pagano, 1990) Highlighted that fiscal consolidation tends to expansionary when loaning facility availed is higher or increasing hurriedly. In this regard researchers argued that investment from private sector results positively to worth full promise for diminution of debt and decrease in the risk premium.

Than (Alesina \& Perotti, 1993), and (Alesina, Alberto; Ardagna, Silvia, 1998) initiate that in connection to the magnitude plus persistence of fiscal inclination, composition of budget matters in defining various private part reaction to the fiscal plan. In addition to the fiscal adjustment which basically depending on cuts in reassign and salary bills tends to lost extended also can be expansionary, but those which basically depending on increase on taxes and a cut within public investment tends to be contra dictionary and no more sustainable (Von Hagon \& Strauch, 2001).

Countries having conflicts like Afghanistan, Iraq face serious challenges while formulating and implementing sound fiscal policy on macroeconomic level. An institutional frame work pointed out with a straightforward and pragmatic plan stance must rapidly be placed in to reestablishes macroeconomic stability plus process for a continuation of economic growth. Within fiscal discipline, conflicts or post conflicts countries tackle a disturbed base of revenue along with need of extra ordinary expenditure.

On the $1^{\text {st }}$ May 2004, European Union increased to the union of 25 member countries, the important aspect of this increase is that: a lot of fresh member countries are passing through a procedure from concerned economy to market economy and majority among them are relatively lower the average income level of EU. Than the level of depression amongst these countries along with their regions are outstanding (Vaitilingam, 2002). 
(Modigliani, 1961) Suggest that swell in public debt shrink the resources stock of economy, also growth rate of the economy will be lowered. As shown by (Saint-Paul, 1992) raise in the level of public liability simply reduce the welfare of economy.

Interestingly according to (EU, 2003) partly the fiscal consolidations parts embark in EU countries within the earlier period were followed by quick increase in economic expansion.

A similar study of (Afonso, Schuknecht, \& Tanzi, 2003) analyzed the performance of communal segment plus competence of 23 OECD countries. The researchers considered that opportunity providing indicators of administration, such as education, health, and infrastructure. This study also used total spending of government for evaluating the level of public sector efficiency, and concluded: when fiscal consolidations acquire place in 1990-2000, there was enhancement in the performance of public sector especially in the countries which were used in the study likewise Greece, Portugal, along with Ireland.

Study of (Nasir, Ahmad, Ali, \& Rehman, 2010) investigated the incidence of synchronization between monetary and fiscal plans in Pakistan, used data as of 1975-2006 with the help of vector auto regression and concluded that there is weak link among these policies, which shows that there is weak link among the policies which shows that there are pathetic reaction of policy creator to dissimilar policies, the reaction of monetary policy to the fiscal fright is too much slow in adjustment of value to their inventive level, nearly after passing the time of two decades. And same case is with the nominal interest rate which after 24 years converges back to its origin, after the inducement of shocks of unemployment in the system. And interest rates are displaces by fiscal surplus from the usual stage, about nineteen years. Same is the reaction of fiscal capricious to the upset in monetary erratic. Joblessness plus fiscal superfluous is displaced by price shocks from their original point for about 21 years, moreover shocks of interest rate carry on to influence fiscal surplus for 24 years.

\section{Methodology}

Data was collected through secondary source of information from ministry of finance government of Pakistan and the economic development variables used as independent variables for analysis are: (Un-employment Rate, Health \& Nutrition expenditure, Exports, Imports, CPI, and Inflation) from 2000-01 to 2009-10 then Pearson correlation and linear regression was applied to check the degree of association of variables by applying the diagnostic tests:

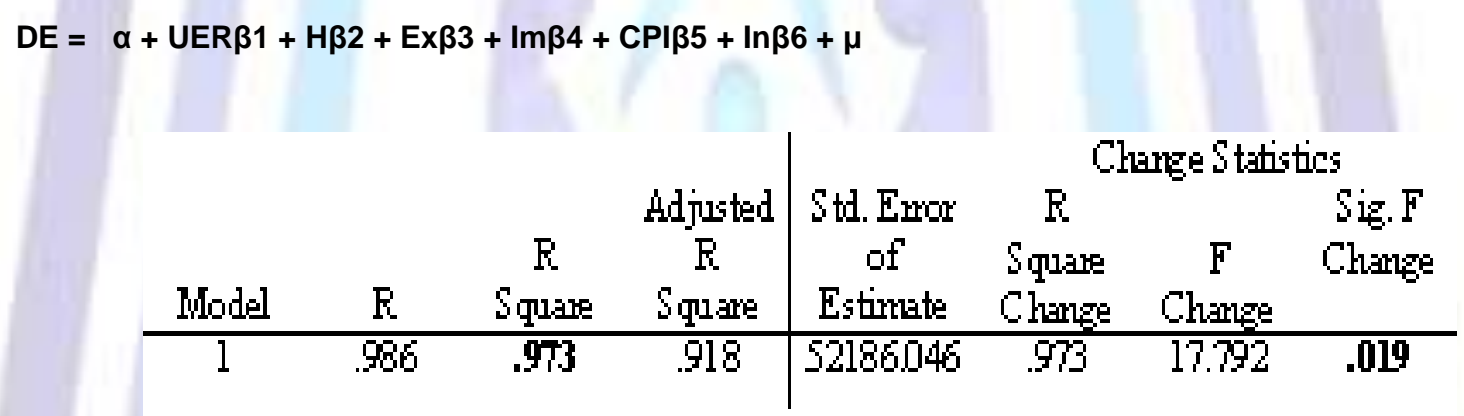

This multiple regression test is applied here to check the strength of six independent (Economic Development) variables with one Development (dependent) variable, the model summary states that model is fit by looking at the Value of R-Square but the significance level matters which is at $\mathbf{. 0 1 9}$ levels.

\begin{tabular}{|c|c|c|c|c|c|}
\hline \multirow[t]{2}{*}{ Model } & \multicolumn{2}{|c|}{$\begin{array}{l}\text { Unstandardized } \\
\text { Coefficients }\end{array}$} & \multirow{2}{*}{$\begin{array}{c}\text { Standardized } \\
\text { Coefficients } \\
\text { Beta }\end{array}$} & \multirow[b]{2}{*}{$t$} & \multirow[b]{2}{*}{$\mathrm{Sig}}$. \\
\hline & $\mathrm{B}$ & Std. Enrox & & & \\
\hline (Constart) & 31130860 & 400796575 & & .078 & .943 \\
\hline Un-Enqloyment Rate & -6162044 & 32498.268 & -.041 & -.190 & .862 \\
\hline Health \& Kh trition & -4666.757 & 9499.594 & -.508 & -.491 & .657 \\
\hline Exports & 650 & 835 & 1.291 & .779 & .493 \\
\hline Imports & .118 & .192 & .500 & 618 & .580 \\
\hline Consumer Price Index & -2055062 & 6991.880 & -.441 & -.294 & .788 \\
\hline Wet Investmerts & .065 & .416 & .035 & .157 & .885 \\
\hline
\end{tabular}

At first instance by looking at the results researcher is not satisfied from the results of the betas of independent variables and also looking at the value of R-Square in the model summary which is not significant means level of significance is .019 
So by revising this test and following stepwise method for making the model significant researcher found that the three of the independent variables amongst the six may be excluded and these are (UER, CPI, and Investments), we got:

\begin{tabular}{|c|c|c|c|c|c|c|c|}
\hline \multirow[b]{4}{*}{ Model } & \multirow[b]{4}{*}{$\mathrm{R}$} & \multirow{4}{*}{$\begin{array}{c}\mathrm{R} \\
\text { Square }\end{array}$} & \multirow{4}{*}{$\begin{array}{c}\text { Aijusted } \\
\mathrm{R} \\
\text { Square }\end{array}$} & \multirow{4}{*}{$\begin{array}{c}\text { Sti. Error } \\
\text { of } \\
\text { Estimate }\end{array}$} & \multicolumn{3}{|c|}{ Cheres Statitios } \\
\hline & & & & & $\mathrm{R}$ & & $\mathrm{Sig} F$ \\
\hline & & & & & Square & $F$ & Change \\
\hline & & & & & Chenze & Charke & \\
\hline 1 & .96 & 97 & .958 & 3745773 & .972 & 0.026 & .010 \\
\hline
\end{tabular}

\begin{tabular}{lc|cccc|}
\multicolumn{1}{c}{ Model } & \multicolumn{2}{c}{ Urstandardized } & Standardized & \\
& $\mathrm{B}$ & Std. Enof & Beta & $\mathrm{t}$ & Siz. \\
\hline (Constart) & -0067.306 & 64494.225 & & -1.251 & .257 \\
Health \& Hutrition & -6085692 & 4069.939 & -.663 & -1.488 & .187 \\
Exports & .427 & 242 & .848 & 1.769 & .127 \\
Imports & .162 & 078 & .794 & 2.074 & .083
\end{tabular}

Revision states that revised model is fit at .972 and significant at .000 levels, values of beta means association of independent variables increased for the predictor (dependent variable).

\section{Conclusion}

Looking at the value of R-square which states that all six independent variables of economic development are rightly predicting the development expenditure while using general approach but when we used the stepwise regression method which clearly escaping or leaving three of them and only using remaining three variables namely Health \& Nutrition, Exports, and Imports are rightly predicting the development expenditure (Dependent Variable) and states that Health \& Nutrition Expenditure is negatively related with development expenditure which is purely policy matter, and Exports, Imports are positively related with development expenditure it is right in the case of exports only but needs serious attention by the policymakers in the case of Imports.

\section{References}

1. Afonso, A., Schuknecht, L., \& Tanzi, V. (2003). Public Sector efficiency: An International Comparison. ECB Working Paper No. 242.

2. Alesina, A., \& Perotti, R. (1993). Income Distribution, Political Instability, and Investment. NBER Working Paper No.4486, National Bureau of Economic Research: Cambridge .

3. Alesina, Alberto; Ardagna, Silvia. (1998). Tales of Fiscal Adjustment. Economic Policy vol 27 (October) , 487-546.

4. Barro, R J. (1991). Economic Growth in a Cross Section of Countries. Quarterly Journal of Economics, vol 104, 407443.

5. Barro, R J. (1990). Government Spending in a Simple Model of Endogenous Growth. Journal of Political Economy vol $98,103-125$.

6. Bird, R. (2004). Administrative Dimensions of Tax Reform. pp. 134-150.

7. Blejer, M., \& Chu, K.-Y. e. (1989). Fiscal Policy, Stablization and Growth in Developing Countries. International Monetary Fund: Washington .

8. Bonney, R. (1999). The Rise of the Fiscal State in Europe. Oxford University Press .

9. Brautigam, D., Fjeldstad, O.-H., \& Moore, M. (2008). Taxation and State-Building in Developing Countries. Cambridge University Press .

10. Brewer, J. (1989). The Sinews of Power: War, Money and the English State. New York: Knopf , 1688-1783.

11. Burgees, R., \& Stern, N. (1993). Taxation and Development. Journal of Economic Literature, vol. 31, 762-830. 
12. Burnside, C., \& Dollar, D. (2000). Aid Policies, and Growth. American Economic Review, vol 90 (September) , 847868.

13. Cukierman, A., Edward, S., \& Tabellini, G. (1992). Seignorage and Political Instability. American Economic Review, vol.82, 537-555.

14. Dincecco, M. (2011). Political Transformation and Public Finances: Europe. Cambridge University Press , 1650-1913.

15. Easterly, W. (2003). Can Foreign Aid Buy Growth? Journal of Economic Perspectives, vol.17 (Summer) , 23-48.

16. EU, E. C. (2003). Public Finances in Emu 2003. Directorate General of Economic and Financial Affairs .

17. Giavazzi, F., \& Pagano, M. (1990). Can Severe Fiscal Contractions be Expansionary? Tales of Two Small European Countries. NBER Macroeconomic Annual 1990 , 75-110.

18. Gordon, R., \& Li, W. (2009). Tax Structure in Developing Countries: Many Puzzles and a Possible Explaination. Journal of Public Economics, vol. 93 , 855-866.

19. Gordon, Roger. (2010). Taxation in Developing Countries: Six Case Studies and Policy Implications. New York: Columbia University Press.

20. Hinrichs, H. H. (1996). A General Theory of Tax Structure Change During Economic Development. Cambridge MA: The Law School of Harward University.

21. Hoffman, P., \& Rosenthal, J.-L. (1997). Political Economy of Welfare and Taxation in Early Modern Europe: Historical Lessons for Economic Development. The Frontier of new institutional economics, San Diego: Academic Press .

22. Hwanjoon, K. (2000). Anti-poverty effectivenessof Taxes and Income Transfers in Welfare States. International Social Security Review 53(4).

23. Kleven, H., Kreiner, C. T., \& Saez, E. (2009). Why can Modern Governments Tax so much? An Agency Model of Firms as Fiscal Intermediaries. NBER Working Paper , 15218.

24. Levi, M. (1988). Of Rule the Revenue. Berkeley: University of California Press .

25. Micael, P. T., \& Smith, C. S. (2006). Economic Development. Pearson Addison Wesley , 110.

26. Migdal, J. S. (1988). Strong Societies and Weak States: State-Society Relations and State Capabilities in the Third World. Princeton University Press .

27. Modigliani, F. (1961). Long-run Implications of Alternative Fiscal Policies, and the Burden of National Debt. Economic Journal 71(284), 730-755.

28. Nasir, M., Ahmad, A., Ali, A., \& Rehman, F. U. (2010). Fiscal and Monetary Policy Coordination: Evidence From Pakistan. International Research Journal of Finance and Economics , 202-213.

29. Newbery, D., \& Stern, N. (1987). The Theory of Taxation for developing Countries. Oxford University Press For World Bank.

30. O'Brien, P. (2005). Fiscal and Financial Preconditions for the Rise of British Naval Hagemony. mimeo, London School of Economics , 1485-1815.

31. Pearson, T., \& Tabellini, G. (2003). The Economic Effects of Constitutions. Cambridge MA: MIT Press

32. Piketty, T., \& Qian, N. (2009). Income Inequality and Progressive Income Taxation in China and India 1986-2015. American Economic Journal: Applied Economics, vol.1 , 53-63.

33. Romer, P. M. (1990). Endogenous Technological Change. Journal of Political Economy, vol.98 (October) , 71-102.

34. Schumpeter, J. A. (1918). The crises of tax state. International economic papers, vol 4 , 5-38.

35. Slemord, J., \& Yitzhaki, S. (2002). Tax Avoidance, Evasion, and Administration. Hand Book of Public Economics, vol. 3 .

36. Tanzi, V. (1987). Quantitative Characteristics of the Tax Systems of Developing Countries. Oxford University Press for World Bank.

37. Tanzi, Vito. (1992). Structural factors and Tax Revenue in Developing Countries. Cambridge University Press .

38. Tilly, C. (1985). Warmaking and State Making as Organized Crime. Cambridge University Press .

39. Vaitilingam, R. (2002). Who's Afraid of the Big Enlargement? . Economic and Social Implications of the European Union's Prospective Eastern Expansion, CEPR Policy Paper No.7 .

40. Von Hagon, J., \& Strauch, R. (2001). Fiscal Consolidations: Quality, Economic Conditions, and Success. Public Choice, vol.109 (December) , 327-346. 